Chirurgia (2018) 113: 524-533

No. 4, July - August

Copyright@ Celsius

http://dx.doi.org/10.21614/chirurgia.113.4.524

\title{
Evaluation of Tumor Response Using Alpha-fetoprotein and Des-gamma-carboxy Prothrombin in Hepatocellular Carcinoma Patients Who Underwent Transarterial Chemoembolization
}

\author{
Razvan Cerban', Carmen Ester', Speranta lacob', Liliana Paslaru², Radu Dumitru ${ }^{3}$, Mugur Grasu ${ }^{3}$, \\ Georgiana Constantin ${ }^{2}$, Irinel Popescu ${ }^{4}$ and Liliana Gheorghe ${ }^{1}$
}

${ }^{1}$ Center for Digestive Diseases and Liver Transplantation, Fundeni Clinical Institute, Carol Davila University of Medicine and Pharmacy, Bucharest, Romania

${ }^{2}$ Department of Biochemistry, Fundeni Clinical Institute, Bucharest Romania

${ }^{3}$ Radiology Department, Fundeni Clinical Institute, Bucharest Romania

${ }^{4}$ Dan Setlacec Centre of General Surgery and Liver Transplantation, Fundeni Clinical Institute, Bucharest, Romania

Corresponding author:

Liliana Gheorghe, MD, PhD

Department of Gastroenterology and Hepatology

Fundeni Clinical Institute, Bucharest

E-mail: drgheorghe@xnet.ro

\section{Abbreviations:}

AFP - alpha-fetoprotein;

DCP - des- $\gamma$-carboxy-prothrombin;

HCC - hepatocellular carcinoma;

TACE - trans-arterial chemoembolization;

BCLC - Barcelona Clinic of Liver Cancer;

ECOG - Eastern Cooperative Oncology

Group;

TTP - time to progression:

PFS - progression-free survival;

OS - overall survival;

\section{Rezumat}

Evaluarea răspunsului tumoral utilizând alfa-fetoproteina și des-gamma-carboxiprotrombina la pacientii cu carcinom hepatocelular tratati prin chemoembolizare trans-arterială

Introducere: Acest studiu are ca scop investigarea utilitãții clinice a determinãrii alfa-feto-proteinei (AFP) şi des-gamma-carboxiprotrombinei (DCP) în evaluarea răspunsului la tratament la o lună, la pacienții cu carcinom hepatocelular $(\mathrm{CHC})$, tratați prin chemoembolizare trans-arterială (TACE).

Metoda: Din martie 2016 până în aprilie 2017 am înrolat prospectiv un număr de 59 de pacienți netratați anterior, diagnosticați cu CHC. Dintre aceştia, 41 de pacienți au efectuat TACE ca modalitate inițială de tratament. Nivelurile serice de AFP şi DCP au fost măsurate şi caracteristicile clinico-patologice au fost determinate. Testul de rang Wilcoxon a fost folosit pentru a compara variabilele la momentul inițial şi după o lună.

Rezultate: 86,4 \% dintre pacienții cu CHC au fost tratați, 27 de pacienți au efectuat TACE clasic, 14 pacienți au fost tratați cu DEB-TACE, 3 pacienți au efectuat ablație prin radiofrecvențã, iar 4 pacienți au beneficiat de transplant hepatic ca tratament inițial. Terapia sistemicã cu Sorafenib a fost începutã în cazul a 3 pacienți $(5 \%)$, iar 8 pacienți nu au efectuat niciun tratament. 
Atât AFP cât şi DCP au scăzut semnificativ după o lună, la pacienții cu CHC tratați (valoarea medie 240.3 vs. $123.7 \mathrm{ng} / \mathrm{mL}, \mathrm{p}=0.020$ ), respectiv (valoarea medie 1376.8 vs. $769 \mathrm{mAU} / \mathrm{mL}, \mathrm{p}=0.0033$ ). Valorile AFP ( 85.5 vs. $18.7 \mathrm{ng} / \mathrm{mL}, \mathrm{p}=0.035)$ şi DCP $(693.2$ vs. $58.2 \mathrm{ng} / \mathrm{mL}, \mathrm{p}=0.0003)$ au fost semnificativ scăzute la pacienții cu răspuns complet după TACE, nu şi la pacienții cu răspuns parțial. S-a observat o scădere a diametrului maxim al nodulului tumoral la pacienții care au efectuat terapie ( 30 vs $27 \mathrm{~mm}, \mathrm{p}=0,02$ ).

Concluzie: Valorile AFP şi DCP au scăzut semnificativ la pacienții ce au obținut răspuns complet post TACE. DCP are o sensibilitate mai bună decât AFP pentru predicția răspunsului, asocierea celor doi markeri nu a adus un beneficiu suplimentar.

Cuvinte cheie: alpha-fetoproteina, des-gamma-carboxiprotrombina, carcinom hepatocelular, chemoembolizare transarterială

\section{Abstract}

Introduction: The aim of the study is to evaluate the role of alpha-fetoprotein (AFP) and des- $\gamma^{-}$ carboxy prothrombin (DCP) in the assessment of treatment response at one month in patients with hepatocellular carcinoma (HCC) treated with trans-arterial chemoembolization (TACE).

Methods: From March 2016 to April 2017 a number of 59 patients diagnosed with HCC were prospectively enrolled. A TACE procedure as initial treatment modality was performed in 41 patients. AFP and DCP serum levels were measured and clinical features were determined for all the patients that were included. The Wilcoxon rank test was used to compare variables at baseline and at one month after the procedure.

Results: Treatment was performed in $86.4 \%$ of the patients diagnosed with HCC, 27 patients received a classical TACE procedure, 14 patients were treated with DEB-TACE, radiofrequency ablation was performed in 3 patients and 4 patients received a liver transplant as initial treatment. Systemic therapy with Sorafenib was started in 3 patients (5\%) and in 8 cases no treatment was performed. AFP value significantly decreased at one month in patients that underwent TACE therapy (median value 240.3 vs. $123.7 \mathrm{ng} / \mathrm{mL}, \mathrm{p}=0.020$ ). The same significant decrease was noted for DCP values (median value 1376.8 vs. $769 \mathrm{mAU} / \mathrm{mL}, \mathrm{p}=0.0033)$. Both AFP ( 85.5 vs. $18.7 \mathrm{ng} / \mathrm{mL}$, $\mathrm{p}=0.035$ ) and DCP values (693.2 vs. $58.2 \mathrm{ng} / \mathrm{mL}, \mathrm{p}=0.0003$ ) were significantly lower only in subjects who achieved complete response after TACE and not in patients with partial response. In patients treated with TACE therapy, there was a down-sizing of the maximum diameter of the tumor nodule (30 vs. $27 \mathrm{~mm}, \mathrm{p}=0.02$ ).

Conclusion: There was a significant decrease of AFP and DCP values after complete response in HCC patients treated with TACE. DCP is a more effective tumor marker in predicting response than AFP, with no benefit found in their combination.

Key words: alpha-fetoprotein, des-gamma-carboxy-prothrombin, transarterial chemoembolization, tumor marker response, hepatocellular carcinoma

\section{Introduction}

Hepatocellular carcinoma (HCC) is the most frequently encountered liver malignancy in the world $(1,2)$. Unlike other malignancies, the incidence and mortality rates of $\mathrm{HCC}$ will continue to increase over the next years in many countries (3). Most of the HCC patients are diagnosed at an advanced disease stage and are not candidates for any curative therapies such as radiofrequency ablation, surgery or liver transplantation (4). 
Although several treatment modalities have been applied to advanced HCC, only trans-arterial chemoembolization (TACE) and Sorafenib have been demonstrated to improve survival. According to Barcelona Clinic of Liver Cancer (BCLC) classification, TACE and Sorafenib are recommended for HCC in the intermediate and advanced stages, respectively (5).

Although there is evidence that TACE may also be used in the treatment of patients with early or advanced HCC, prognosis on the longterm of patients treated with TACE as initial therapy varies greatly because of the heterogeneity of HCC tumors, tumor burden, as well as liver function and disease etiology (6).

Therefore, identifying which patients would benefit most from TACE and assessing the efficiency of this treatment is important for determining the most effective therapeutic strategy in every patient.

Intra-arterial chemotherapeutic agents mixed with a solution of lipiodol also known as classical TACE (cTACE) cause cytotoxic damage in tumor cells which associates with ischemia as a result of embolization of the feeding vessels by gelatine or Gelform particles (7).

Drug-eluting beads chemoembolization (DEBDOX TACE) had been developed with the objectives of achieving higher doses of the intraarterial chemotherapeutic agent retained within the tumor and to reduce systemic side effects (8).

The indications for DEBDOX TACE are similar to those for cTACE. DEBDOX may be a better option, particularly in patients with Child-Pugh B, Eastern Cooperative Oncology Group (ECOG) grade 2, Barcelona Clinic Liver Cancer (BCLC) C, bilobar disease or in cases with mild cardiac failure (9).

Since the 1970s the serum a-fetoprotein (AFP) is the most widely-used HCC biomarker and many physicians use AFP in clinical practice for HCC diagnosis. Several studies showed a correlation between AFP dynamics and radiologic response, time to progression (TTP) and overall survival (OS) in HCC patients treated with loco-regional therapies $(10,11)$.

Des gamma carboxy prothrombin (DCP) is an abnormal prothrombin protein that is present at higher levels in the serum of HCC patients and has been identified as a highly specific marker for HCC and a predictor of the prognosis although controversies remain (12).

The primary aim of the present study is to determine, in clinical practice, the utility of AFP and DCP as tumor response predictors in treatment naive $\mathrm{HCC}$ patients undergoing TACE.

\section{Materials and Methods}

\section{Ethical Statement}

The study design was approved by Fundeni Clinical Institute Ethical Committee. All patients signed an informed consent in written form before they underwent diagnostic and therapeutic procedure at the time of hospitalization. This study complied with the guidelines and principles of the declaration of Helsinki.

\section{Patients}

A total of 59 patients with HCC (41 of them receiving TACE as the initial treatment modality) were enrolled at Fundeni Clinical Institute from March 2016 to April 2017.

All patients were newly diagnosed with HCC, without any previous HCC treatment and none had extrahepatic malignancy at the time of their diagnosis. HCC was diagnosed based on histological findings or typical imaging characteristics as defined by the EASL and AASLD guidelines (13). HCC staging was determined using the Barcelona Clinic Liver Cancer (BCLC) staging system. None of the patients had the indications for surgical resection, or the subjects refused the surgery as initial treatment. The patients were included according to the following criteria: older than 18 years and expected survival time longer than 6 months; no history of surgery, chemotherapy, radiotherapy or other locoregional therapy; no liver transplantation history, liver function categorized to class A according to Child classification.

The exclusion criteria were: liver function severely damaged with hepatic cirrhosis decompensation; poor overall health status and unable 
to tolerate the procedure, impaired renal function and severe heart disease, extrahepatic metastasis.

Plasma samples were obtained from all the patients included in the study for AFP and DCP quantification. Clinical and laboratory information at the time of diagnosis were prospectively collected for all the patients and included liver biochemistries (AST, ALT, GGT, alkaline phosphatase, total and direct bilirubin, albumin), platelet count, INR, creatinine, HBV and HCV serologies.

\section{Therapeutic and Response-Evaluation Protocol}

All included patients underwent complete blood count, biochemistry for liver and renal function, blood type, coagulation tests, ultrasound examination and CT examination and upper endoscopy for esophageal varices evaluation. In patients that were found to have high risk esophageal varices a band ligation was performed and the TACE procedure was postponed for 4 weeks.

After local anesthesia through $5-10 \mathrm{ml} 2 \%$ Xiline injection $1 \mathrm{~cm}$ under the inguinal ligament, TACE was performed using Seldinger technique. After right femoral arteriopunction, a $5 \mathrm{~F}$ stealth and catheter was placed. Then a high-pressure injector was used for visualization of the celiac trunk artery or superior mesenteric artery, to locate the position and diameter of the tumor lesion and also to confirm the supportive artery for the tumor. cTACE was conducted using a solution of 50 $\mathrm{mg}$ doxorubicin mixed with lipiodol and a contrast agent. Gelatin sponge particles were subsequently used for embolization which was completed when the entire tumor blood supply artery was blocked and tumor staining vanished entirely.

In patients that underwent DEBDOX, TACE was done using DC Beads ${ }^{\circledR}$ particles (Biocompatibles, Surrey, United Kingdom) loaded with doxorubicin hydrochloride.

After the procedure, the puncture point was pressed for 15 minutes, bandaged and sent back to ward, followed by careful monitoring of blood pressure, heart rate and breathe. Patients were fasted for further 4 hours and right lower limb was immobilized for 24 hours. The puncture point was further checked for potential hemorrhage and dorsal pedis artery was checked for a pulse.

Radiological response evaluation using CT or MRI and tumor marker response were evaluated 4-6 weeks after TACE. If remaining viable tumor was identified by CT or MRI examination, a new session of TACE was repeated.

\section{Tumor Marker Response Evaluation}

Baseline AFP and DCP levels were determined before TACE. In the follow up period, marker were checked at 4-6 weeks after TACE concurrent with CT or MRI. Automated chemiluminescent microparticle immunoassays (ARCHITECT AFP 3P36; ARCHITECT PIVKA-II 2P4) were used for determining serum AFP and DCP using the Abbott ${ }^{\mathrm{TM}}$ Architect iSystem 2000 analyser in the Department of Biochemistry at Fundeni Clinical Institute, Bucharest.

\section{Statistical Analysis}

To compare continuous variables the MannWhitney test was used and Fisher's exact test was employed for categorical variables. For comparing variables at baseline and after one month, the Wilcoxon rank test was used. Age, sex, etiology, previous anti-viral therapy, Child Pugh classification, GGT, AST/ALT, baseline AFP and DCP, BCLC stage, number of tumors, size of tumors were collected at baseline. Initial serum markers (AFP, DCP) and the diameter of the tumors were compared with one month post TACE values, to assess the response. To determine the optimal cut-offs for predicting tumor response receiver operating curves (ROC) were constructed. Correlation analysis was used to identify relationships between the biomarkers. Two tailed $\mathrm{P}<0.05$ is regarded as significant difference.

Statistical analyses were performed using Medcalc ver. 13.3.3.0 software (Medcalc Software). 


\section{Results}

We included 59 newly diagnosed HCC patients, 41 of them received TACE, radiofrequency ablation was performed in 3 patients and 4 patients received a liver transplant as initial treatment. Systemic therapy with Sorafenib was started in 3 patients (5\%) and in 8 cases no treatment was performed. The median age in the TACE group was 60 years and male gender predominated $(n=22$, $53.6 \%)$. Hepatitis $\mathrm{C}$ virus was the most common etiology of HCC ( $n=27,65.8 \%)$, followed by HBV + HDV cirrhosis ( $\mathrm{n}=9,21.9 \%)$. Ten patients (24.4\%), all with HCV cirrhosis had antiviral treatment before HCC diagnosis. Seven patients achieved sustained virological response (SVR) after interferon free regimens treatment and the rest of them were previously treated with interferon plus ribavirin without SVR (Table 1).

A number of 43 patients $(72,8 \%)$ out of the initial 59 patients were within the Milan criteria (single nodule $<5 \mathrm{~cm}$ or three nodules each $<3 \mathrm{~cm}$ in diameter).

The Areas under the ROC Curve (AUC) of serum AFP, serum DCP, according to Milan criteria were 0.575 (95\% CI: 0.397 to 0.740$)$ and 0.845 (95\% CI $0.683-0.945)$, with the best cut-off score of $120.66 \mathrm{ng} / \mathrm{mL}$, and 1110.2 $\mathrm{mAU} / \mathrm{mL}$ respectively. The sensitivity and specificity for AFP and DCP at this cut-off score were $50.0 \%$, and $86.21 \%, 66.67 \%$ and 96.5\% and respectively (Fig. 1).

There was a significant difference in DCP values $(p=0.0005)$ between the patients who met the Milan criteria and the patients outside Milan but no significance for AFP ( $\mathrm{p}=0.67)$ (Fig. 2).

We found no significant difference of the inital AFP and DCP values between HBV and HCV patients groups $(p=0.28$ for $\mathrm{AFP}$ and $\mathrm{p}=0.17$ for DCP).

From the total number of patients, 41 were eligible for TACE and were considered in the final study, in 27 of them we performed cTACE and 14 patients had a DEBDOX procedure.

Most of the patients ( $\mathrm{n}=30,73.1 \%$ ) had one nodule at the time of the diagnosis with a mean diameter of $32.4 \mathrm{~mm}(16-51 \mathrm{~mm})$. A number of
Table 1. Patients characteristics

\begin{tabular}{|c|c|}
\hline Characteristics & Values $(n=41)$ \\
\hline Age, (range) & $60 \pm 8.5(42-80)$ \\
\hline Gender, $n$ (male) & $22(53.6 \%)$ \\
\hline \multicolumn{2}{|l|}{ Etiology } \\
\hline $\mathrm{HBV}+\mathrm{HDV}$ & $9(21.9 \%)$ \\
\hline HCV & $27(65.8 \%)$ \\
\hline Alcohol & $4(9.7 \%)$ \\
\hline Others & $1(2.43 \%)$ \\
\hline Antiviral treatment before HCC & $10(24.4 \%)$ \\
\hline \multicolumn{2}{|l|}{ Child-Pugh class } \\
\hline A & $39(95.1 \%)$ \\
\hline B & $2(4.9 \%)$ \\
\hline Platelet, $\times 10^{3} / \mathrm{L}$ & $94.4 \pm 39.9$ \\
\hline Creatinine, $\mathrm{mg} / \mathrm{dL}$ & $1 \pm 0.8$ \\
\hline Albumin, $g / L$ & $3.5 \pm 0.7$ \\
\hline Bilirubin, $\mathrm{mg} / \mathrm{dL}$ & $1.7 \pm 1.6$ \\
\hline $\mathrm{ALT}, \mathrm{UI} / \mathrm{L}$ & $54 \pm 59.3$ \\
\hline INR & $1.22 \pm 0.33$ \\
\hline Primary prophylactic band ligation & $5(12.2 \%)$ \\
\hline \multicolumn{2}{|l|}{ Tumor number } \\
\hline 1 & $30(73.1 \%)$ \\
\hline 2 & $8(19.5 \%)$ \\
\hline 3 & $2(4.87 \%)$ \\
\hline$>3$ & $1(2.43)$ \\
\hline Tumor size, mm & $32.4 \pm 11.6$ \\
\hline \multicolumn{2}{|c|}{ Serum markers at baseline, median (range) } \\
\hline AFP, $\mathrm{ng} / \mathrm{ml}$ & $240.3 \pm 523.1$ \\
\hline $\mathrm{DCP}, \mathrm{mAU} / \mathrm{ml}$ & $1376.8 \pm 3072.8$ \\
\hline \multicolumn{2}{|l|}{ Treatment } \\
\hline cTACE & $27(65.8 \%)$ \\
\hline DEBDOX & $14(34.1 \%)$ \\
\hline Liver transplant after TACE procedure & $6(14.63 \%)$ \\
\hline \multicolumn{2}{|l|}{ Treatment response } \\
\hline $\mathrm{CR}$ & $20(48.7 \%)$ \\
\hline PR & $21(51.2 \%)$ \\
\hline Follow up duration, months & $12.3 \pm(1-22)$ \\
\hline \multicolumn{2}{|l|}{ Survival outcome, $\mathrm{n}$} \\
\hline Dead & $4(9.75 \%)$ \\
\hline Alive & $35(85.3 \%)$ \\
\hline Unknown & $2(8.87)$ \\
\hline
\end{tabular}

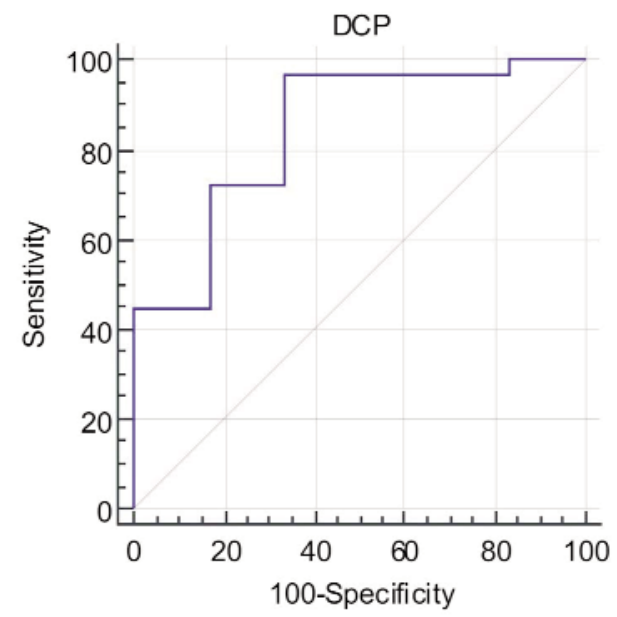

Figure 1. ROC curve for DCP according to Milan 

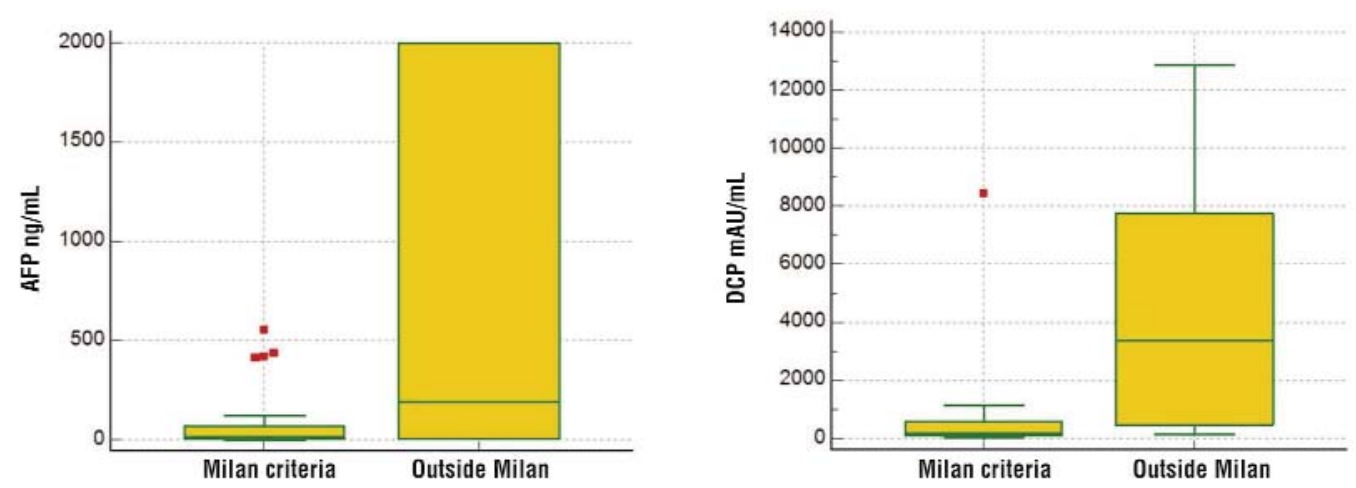

Figure 2. Distribution of AFP and DCP values according to Milan criteria
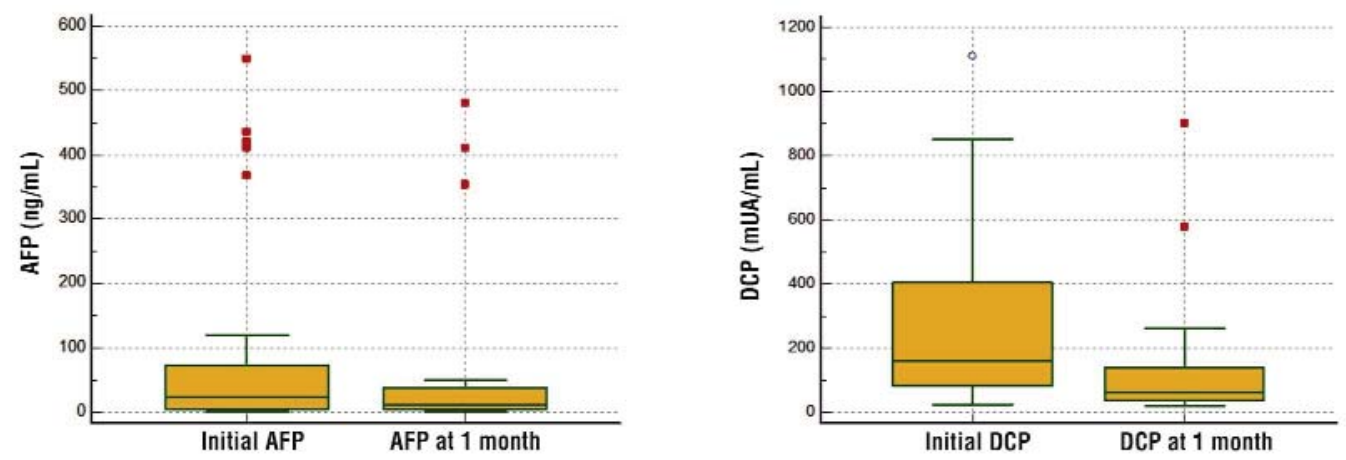

Figure 3. AFP and DCP response at 1 month post TACE

8 patients had 2 nodules and 1 patient had multicentric HCC at the time of diagnosis. Complete response was achieved in 20 patients (48.7\%) and 21 patients displayed partial response at one month. The mean baseline AFP and DCP values were $240.3(1.07-2000 \mathrm{ng} / \mathrm{dl})$ and 1376.8 (23.8-12860 mAU/mL), respectively (Fig. 3).
There was a significant decrease of AFP value after one month in patients with cTACE ( 279.3 vs. $152.9 \mathrm{ng} / \mathrm{mL}, \mathrm{p}=0.046$ ), but not in patients in whom DEBDOX was performed (83.9 vs. $14.5 \mathrm{ng} / \mathrm{mL}, \mathrm{p}=0.296$ ) (Table 2 ).

We noted that DCP value decreased significantly after one month in patients with cTACE (1698.4 vs. $950 \mathrm{mAU} / \mathrm{mL}, \mathrm{p}=0.015$ ), but managed

Table 2. AFP and DCP responses post TACE

\begin{tabular}{|c|c|c|c|}
\hline & Initial value(mean); median & 1 month after TACE (mean); median & $\mathrm{p}$ value \\
\hline AFP & $240.3 ; 32.1 \mathrm{ng} / \mathrm{mL}$ & $123.7 ; 11.2 \mathrm{ng} / \mathrm{mL}$ & $p=0.020$ \\
\hline DCP & $1376.8 ; 179.5 \mathrm{mAU} / \mathrm{mL}$ & $769 ; 64 \mathrm{mAU} / \mathrm{mL}$ & $p=0.0033$ \\
\hline AFP CTACE & $279.3 ; 23 \mathrm{ng} / \mathrm{mL}$ & $152.9 ; 11 \mathrm{ng} / \mathrm{mL}$ & $p=0.046$ \\
\hline AFP DEBDOX & $83.9 ; 40.4 \mathrm{ng} / \mathrm{mL}$ & $14.5 ; 11.8 \mathrm{ng} / \mathrm{mL}$ & $p=0.296$ \\
\hline DCP CTACE & $1698.4 ; 192 \mathrm{mAU} / \mathrm{mL}$ & $950 ; 60.6 \mathrm{mAU} / \mathrm{mL}$ & $p=0.015$ \\
\hline DCP DEBDOX & $197.6 ; 105.5 \mathrm{mAU} / \mathrm{mL}$ & $105.4 ; 71.6 \mathrm{mAU} / \mathrm{mL}$ & $p=0.062$ \\
\hline AFP complete response & $85.5 ; 21.8 \mathrm{ng} / \mathrm{mL}$ & $18.7 ; 8.5 \mathrm{ng} / \mathrm{mL}$ & $p=0.035$ \\
\hline DCP complete response & $693.2 ; 160.5 \mathrm{mAU} / \mathrm{mL}$ & $58.2 ; 40 \mathrm{mAU} / \mathrm{mL}$ & $p=0.0003$ \\
\hline
\end{tabular}



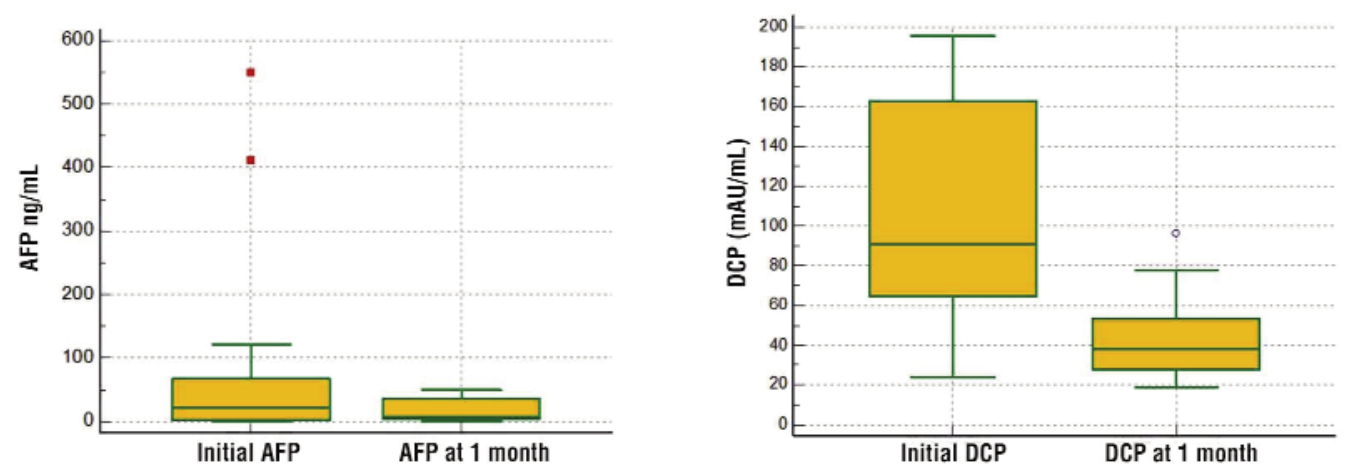

Figure 4. AFP and DCP response at 1 month post TACE in patients with ccomplete response

to reach only marginal significance in $\mathrm{HCC}$ patients in which DEBDOX TACE was performed (197.6 vs. $105.4 \mathrm{mAU} / \mathrm{mL}, \mathrm{p}=0.062$ ). Both AFP (85.5 vs. $18.7 \mathrm{ng} / \mathrm{mL}, \mathrm{p}=0.035)$ and DCP values (693.2 vs. $58.2 \mathrm{ng} / \mathrm{mL}, \mathrm{p}=0.0003)$ were significantly lower only in patients who achieved complete response after a TACE procedure and not in patients with partial tumor response (Fig. 4).

For complete response evaluation, the AUC for serum DCP was 0.903 (95\% CI 0.730 - 0.982) which was significantly better $(p=0.05)$ than for AFP 0.662 (95\% CI: 0.459 - 0.828). The calculated cut-off values were for AFP $\leq 5.05$ $\mathrm{ng} / \mathrm{mL}$ (sensitivity $=33.3 \%$, specificity $=100 \%$ ) and for $\mathrm{DCP} \leq 53.46 \mathrm{mAU} / \mathrm{mL}$ (sensitivity = $73.3 \%$, specificity $=100 \%$ ). The association of AFP to DCP did not improve further the ability to differentiate between complete and partial response (Fig. 5).

All 41 patients that underwent TACE completed 6-month follow-up visits, among them four patients experienced a relapse within 6 months. The AFP, DCP statuses before treatment were not associated with short-term recurrence. The recurrence rate of the patients with increased AFP values measured at 4 weeks after TACE was greater than that of patients which had a normal AFP after the procedure $(p=0.032)$. DCP was moderately correlated $(\mathrm{p}=0.001, \mathrm{r}=0.5)$ with the initial maximum diameter of the tumor nodule but there was no correlation with the AFP value and the tumor diameter (Fig. 6).

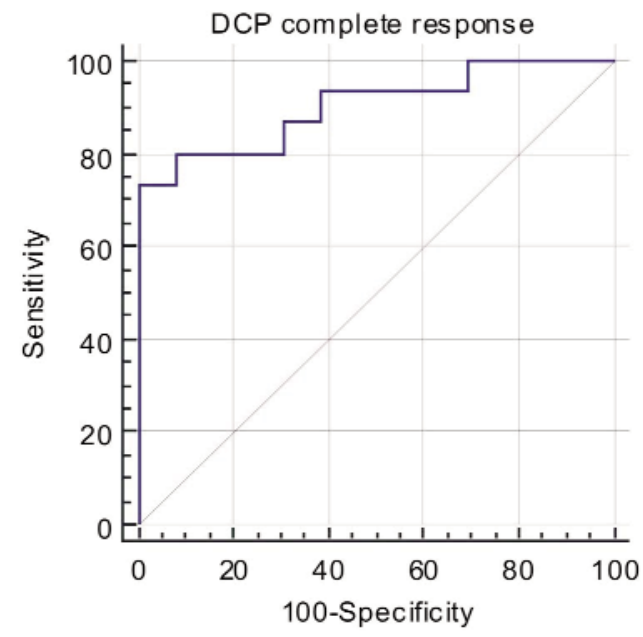

Figure 5. ROC curve for DCP in patients with complete response

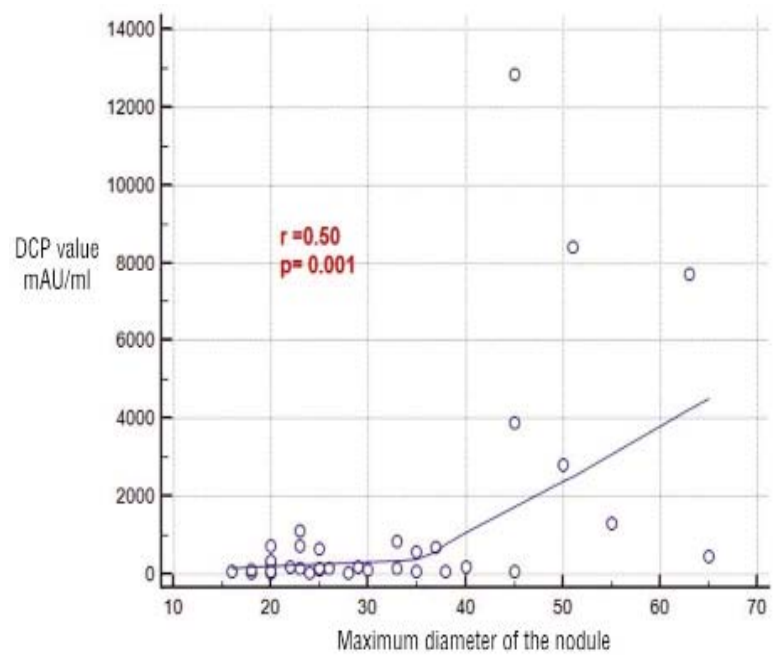

Figure 6. Correlation between DCP and initial nodule diameter 
When we evaluated the correlation between the maximum diameter of the tumor and DCP value after TACE we found the same moderate correlation $(\mathrm{p}=0.002, \mathrm{r}=0.55)$ (Fig. 7). No correlation with the AFP value and the maximum tumor diameter after TACE was found.

In patients treated with TACE therapy, there was a down-sizing of the maximum diameter of the tumor nodule $(30$ vs. $27 \mathrm{~mm}$, $\mathrm{p}=0.02$ ).

\section{Discussion}

In comparison to other types of cancer, HCC is characterized by the ability to produce a significant variety of biomarkers. The immediate estimation of treatment response and disease prognosis plays a pivotal role for the clinical outcome of patients treated with locoregional therapies, due to the high rates of recurrence. From this point of view the evaluation of serum biomarkers' values after TACE may reflect the tumor behavior and the possibility of evaluating disease progression and prognosis (14).

Tumor response evaluation using CT or MRI after loco-regional treatment is the most widely used approach to decide whether to treat further, repeating the same therapeutic modality or change the treatment strategy.

Imaging methods have a high cost and a cancer risk due to repeated radiation exposure of the patient, whereas tumor marker evaluation after tumor treatment is rapid, easier to estimate, and less expensive. For those reasons, the clinical implications of tumor response evaluation using tumor markers have been continuously investigated in recent years.

Serum DCP levels have been measured in this clinical setting for decades in some countries especially from Asia, but this is the first study which determines DCP levels in patients from Romania.

HCC biomarkers AFP and DCP have also been reported to be predictive of specific clinicopathological variables representing the malignant potential of the tumor.

Several studies $(15,16)$ revealed that pretreatment AFP levels > $400 \mathrm{ng} / \mathrm{mL}$ and DCP > $200 \mathrm{mAU} / \mathrm{mL}$ were indicative of larger tumor

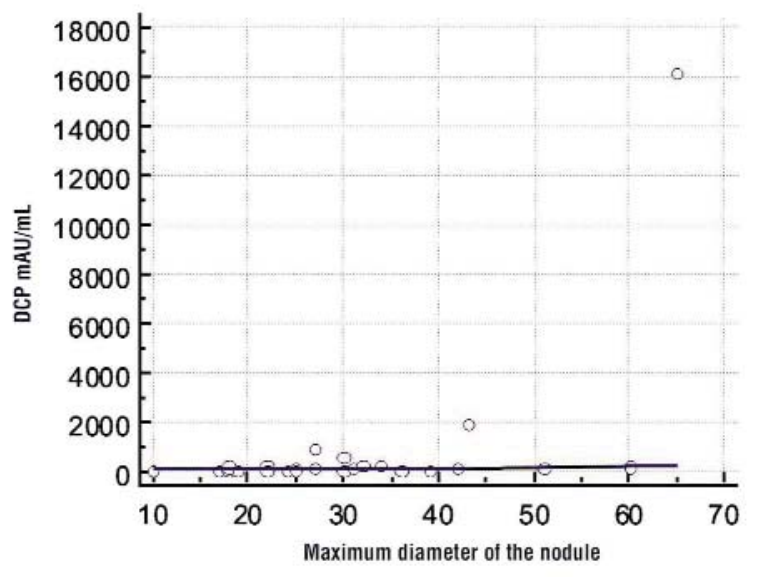

Figure 7. Correlation between DCP value and nodule diameter at 1 month

size, greater tumor numbers, a later clinical phase, bile duct invasion, vascular invasion and a shorter median survival time. We were able to demonstrate in a cohort of patients from Romania that DCP levels are strongly associated with tumor diameter and outside Milan criteria. The correlation of DCP with tumor burden should be taken into account when considering patients for transplant listing due to the high risk of HCC recurrence.

Radiological morphology after TACE can be in some cases nonhomogenous and inconsistent because of irregular uptake of lipiodol and necrosis and this can compromise imagingbased measurements of tumor responses. A previous paper evaluated the serum levels of AFP and DCP in efforts to overcome this limitation and reported that the reductions post treatment in both AFP and DCP levels in patients exhibiting a CR were significantly greater than in those who did not achieve CR (17). In addition, a strong association between the radiological response and serum AFP and DCP levels was reported by the same authors (15).

In another study the AFP serum level was significantly correlated with the radiological response post TACE, but the serum level of DCP was not (18).

We demonstrated that both AFP and DCP values had a significant decrease at one month in all patients treated with TACE thus DCP can be considered alongside AFP a very useful 
biomarker in following patients after TACE therapy.

Several studies demonstrated that the initial AFP level prior to surgery can be used as a prognostic factor for early as well as late recurrence in patients with cirrhosis and preoperative DCP level is a predictor for invasion of the portal vein or intrahepatic spread of HCC after tumor resection $(19,20)$.

Riaz et al. (21) proposed AFP response after loco-regional therapy as a method of evaluating tumor response and survival and as an early objective screening tool for disease progression by imaging. The supplementary role of the AFP level changes for tumor response evaluation, prediction of survival and extrahepatic metas ${ }^{-}$ tasis in patients undergoing hepatic arterial chemotherapy, and also for antiangiogenic treatment such as Sorafenib and Bevacizumab has been proposed in some papers $(22,23)$.

In our study we focused on the predictive value of the responses of AFP and DCP and their combination for complete response at one month after TACE which is different from previous studies focusing on the prognostic value of baseline AFP and DCP in all patients with treatment-naïve HCC.

In our group of patients, although both AFP and DCP levels decreased at one month after TACE in patients who achieved complete response, only $\mathrm{DCP}$ values $(\mathrm{AUC}=0.903)$ and not AFP $(\mathrm{AUC}=0.662)$ at 1 month were significantly correlated $(p=0.05)$ with complete response and thus DCP is a better biomarker than AFP for predicting treatment response and prognosis.

At 1 month a cut-off value for $\mathrm{DCP} \leq 53.46$ $\mathrm{mAU} / \mathrm{mL}$ was predictive of complete response post TACE with a sensitivity of $73 \%$ which is higher than the sensitivity for AFP of only $33.3 \%$ which makes DCP an acceptable marker for TACE response screening.

From this point of view, predicting treatment outcomes in the early period following initial TACE is extremely important. We consider that the results from our study can help physicians to determine the disease course in each patient more precisely and decide the future treatment plan following an initial TACE procedure.
The limitations of the present study are the fact that AFP and DCP levels were measured only at inclusion and at 4 weeks following TACE treatment and the patient population was rather small and inhomogeneous. Further validation studies with larger patient cohorts may help to verify the usefulness of such this approach.

\section{Conclusion}

In conclusion, AFP and DCP responses at 1 month appear to be significant predictors of the effects of TACE and complete radiological response in patients with HCC. AFP and DCP values seem to be a good predictor of HCC short-term recurrence, and we need to increase the sample size and extend the follow-up time in future research.

There was a significant decrease of AFP and DCP values in patients treated with TACE, who achieved complete response, which may be used to predict more accurately the outcomes after TACE by developing a treatment algorithm to incorporate tumor marker response and radiologic response to compensate for each other's drawbacks. DCP was proved to be a more effective tumor marker in predicting response than AFP. No benefit was found in their combination.

AFP and DCP levels, especially in the early phase of the treatment, should be further explored in larger clinical trials and a greater number of patients with a DEBDOX procedure should be included into future studies.

\section{Conflicts of Interest}

No conflict of interest.

\section{References}

1. El-Serag HB, Mason AC. Rising incidence of hepatocellular carcinoma in the United States. N Engl J Med. $1999 ; 340(10)$ : 745-50.

2. Parkin DM, Bray F, Ferlay J, Pisani P. Estimating the world cancer burden: Globocan 2000. Int J Cancer. 2001;94(2):153-6.

3. Davis GL, Alter MJ, El-Serag H, Poynard T, Jennings LW. Aging of hepatitis C virus (HCV)-infected persons in the United States: a multiple cohort model of HCV prevalence and disease progression. Gastroenterology. 2010;138(2):513-21, 521.e1-6. Epub 2009 0ct 25.

4. Bruix J, Sherman M, Llovet JM, Beaugrand M, Lencioni R, Burroughs AK, et al. Clinical management of hepatocellular carcinoma. Conclusions of the Barcelona-2000 EASL conference. 
European Association for the Study of the Liver. J Hepatol. 2001; 35(3):421-30.

5. Bruix J, Sherman M; American Association for the Study of Liver Diseases. Management of hepatocellular carcinoma: an update. Hepatology. 2011;53(3):1020-2.

6. Raoul JL, Sangro B, Forner A, Mazzaferro V, Piscaglia F, Bolondi L, et al. Evolving strategies for the management of intermediate-stage hepatocellular carcinoma: available evidence and expert opinion on the use of transarterial chemoembolization. Cancer Treat Rev. 2011; 37(3):212-20. Epub 2010 Aug 17.

7. Lencioni R, Crocetti L. Local-regional treatment of hepatocellular carcinoma. Radiology. 2012;262(1):43-58.

8. Varela M, Real MI, Burrel M, Forner A, Sala M, Brunet M, et al. Chemoembolization of hepatocellular carcinoma with drug eluting beads: efficacy and doxorubicin pharmacokinetics. J Hepatol. 2007; 46(3):474-81. Epub 2006 Nov 29.

9. Lammer J, Malagari K, Vogl T, Pilleul F, Denys A, Watkinson A, et al. Prospective randomized study of doxorubicin-eluting-bead embolization in the treatment of hepatocellular carcinoma: results of the PRECISION V study. Cardiovasc Intervent Radiol. 2010; 33(1):41-52. Epub 2009 Nov 12.

10. Youk CM, Choi MS, Paik SW, Ahn BH, Lee JH, Koh KC, et al. Early diagnosis and improved survival with screening for hepatocellular carcinoma. Taehan Kan Hakhoe Chi. 2003;9(2):116-23. Korean

11. Kim BK, Ahn SH, Seong JS, Park JY, Kim do Y, Kim JK, et al. Early alpha fetoprotein response as a predictor for clinical outcome after localized concurrent chemoradiotherapy for advanced hepatocellular carcinoma. Liver Int. 2011;31(3):369-76. Epub 2010 Nov 17.

12. Sharma B, Srinivasan R, Chawla YK, Kapil S, Saini N, Singla B, et al. Clinical utility of prothrombin induced by vitamin $\mathrm{K}$ absence in the detection of hepatocellular carcinoma in Indian population. Hepatol Int. 2010;4(3):569-76.

13. European Association for the Study of the Liver, European Organisation for Research Treatment of Cancer. EASL-EORTC clinical practice guidelines: management of hepatocellular carcinoma. Hepatol. 2012;56(4):908-43.

14. Tampaki M, Doumba PP, Deutsch M, Koskinas J. Circulating biomarkers of hepatocellular carcinoma response after locoregional treatments: New insights. World J Hepatol. 2015;7(14):1834-42.
15. Yamamoto $\mathrm{K}$, Imamura $\mathrm{H}$, Matsuyama $\mathrm{Y}$, Kume $\mathrm{Y}$, Ikeda $\mathrm{H}$, Norman GL, et al. AFP, AFP-L3, DCP, and GP73 as markers for monitoring treatment response and recurrence and as surrogate markers of clinicopathological variables of HCC. J Gastroenterol. 2010; 45(12):1272-82. Epub 2010 Jul 13.

16. Saito $\mathrm{Y}$, Shimada M, Utsunomiya $\mathrm{T}$, Morine $\mathrm{Y}$, Imura S, Ikemoto $\mathrm{T}$, et al. Prediction of recurrence of hepatocellular carcinoma after curative hepatectomy using preoperative Lens culinaris agglutininreactive fraction of alpha-fetoprotein. Hepatol Res. 2012;42(9): 887-94.

17. Park WH, Shim JH, Han SB, Won HJ, Shin YM, Kim KM, et al. Clinical utility of des-gamma-carboxyprothrombin kinetics as a complement to radiologic response in patients with hepatocellular carcinoma undergoing transarterial chemoembolization. J Vasc Interv Radiol. 2012; 23(7):927-36.

18. Lee YK, Kim SU, Kim DY, Ahn SH, Lee KH, Lee DY, et al. Prognostic value of alphafetoprotein and des-gamma-carboxy prothrombin responses in patients with hepatocellular carcinoma treated with transarterial chemoembolization. BMC Cancer. 2013;13:5.

19. Cucchetti A, Piscaglia F, Caturelli E, Benvegn L, Vivarelli M, Ercolani $G$, et al. Comparison of recurrence of hepatocellular carcinoma after resection in patients with cirrhosis to its occurrence in a surveilled cirrhotic population. Ann Surg Oncol. 2009;16(2): 413-22.

20. Inagaki Y, Tang W, Makuuchi M, Hasegawa K, Sugawara Y, Kokudo N. Clinical and molecular insights into the hepatocellular carcinoma tumour marker des- $\gamma$-carboxyprothrombin. Liver Int. 2011;31(1):22-35.

21. Riaz A, Ryu RK, Kulik LM, Mulcahy MF, Lewandowski RJ, Minocha J, et al. Alpha-fetoprotein response after locoregional therapy for hepatocellular carcinoma: oncologic marker of radiologic response, progression, and survival. J Clin Oncol. 2009;27(34):5734-42.

22. Lee MH, Kim SU, Kim DY, Ahn SH, Choi EH, Lee KH, et al. Early ontreatment predictions of clinical outcomes using AFP and DCP responses in patients with advanced hepatocellular carcinoma. J Gastroenterol Hepatol. 2012;27(2):313-22.

23. Shao YY, Lin ZZ, Hsu C, Shen YC, Hsu CH, Cheng AL. Early alphafetoprotein response predicts treatment efficacy of antiangiogenic systemic therapy in patients with advanced hepatocellular carcinoma. Cancer. 2010;116(19):4590-6. 